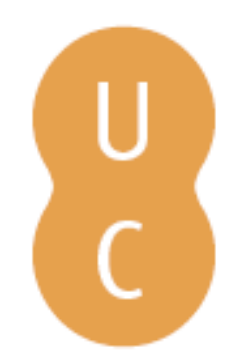

\title{
pompalina
}

\section{Participation in organized sport among urban mexican youth}

$\begin{array}{ll}\text { Autor(es): } & \text { Siegel, Shannon R; Peña Reyes, Maria E; Cárdenas Barahona, Eyra E; } \\ \text { Malina, Robert M }\end{array}$

Publicado por: Imprensa da Universidade de Coimbra

URL

persistente: URI:http://hdl.handle.net/10316.2/32080

DOI: $\quad$ DOI:http://dx.doi.org/10.14195/978-989-26-0507-4_3

Accessed : $\quad$ 26-Apr-2023 15:54:16

A navegação consulta e descarregamento dos títulos inseridos nas Bibliotecas Digitais UC Digitalis, UC Pombalina e UC Impactum, pressupõem a aceitação plena e sem reservas dos Termos e Condições de Uso destas Bibliotecas Digitais, disponíveis em https://digitalis.uc.pt/pt-pt/termos.

Conforme exposto nos referidos Termos e Condições de Uso, o descarregamento de títulos de acesso restrito requer uma licença válida de autorização devendo o utilizador aceder ao(s) documento(s) a partir de um endereço de IP da instituição detentora da supramencionada licença.

Ao utilizador é apenas permitido o descarregamento para uso pessoal, pelo que o emprego do(s) título(s) descarregado(s) para outro fim, designadamente comercial, carece de autorização do respetivo autor ou editor da obra.

Na medida em que todas as obras da UC Digitalis se encontram protegidas pelo Código do Direito de Autor e Direitos Conexos e demais legislação aplicável, toda a cópia, parcial ou total, deste documento, nos casos em que é legalmente admitida, deverá conter ou fazer-se acompanhar por este aviso.

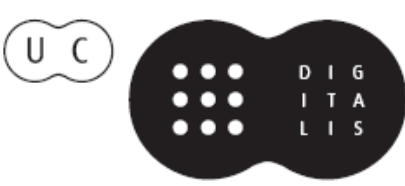


Manuel J. Coelho e Silva António J. Figueiredo Marije T. Elferink-Gemser Robert M. Malina
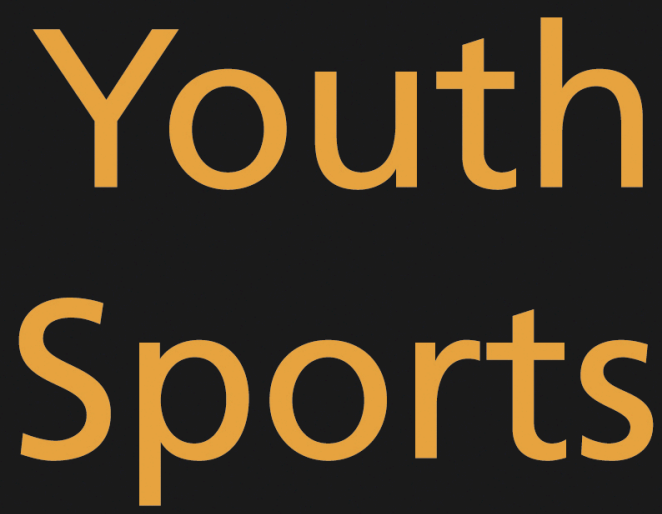

Participation, Trainability and Readiness 


\section{EDIC̣̃̃o}

Imprensa da Universidade de Coimbra

Email: imprensauc@ci.uc.pt

URL: http://www.uc.pt/imprensa_uc

Vendas online: http://siglv.uc.pt/imprensa/

\section{CONCEPÇÃO GRÁFICA}

António Barros

\section{EXECUÇÃo GRÁFICA}

Sereer, Soluções Editoriais

ISBN

978-989-8074-98-0

DEPÓSITO LEGAL

297937/09

OBRA PUBLICADA COM O APOIO DE:

FCT Fundação para a Ciência e a Tecnologia

MINISTÉrio DA CIÊNCIA, TECNOLOGIA E ENSINO SUPERIOR Portugal

Sub-projecto PRONTALSPORT 
Manuel J. Coelho e Silva António J. Figueiredo Marije T. Elferink-Gemser

Robert M. Malina

Editors

\section{Youth

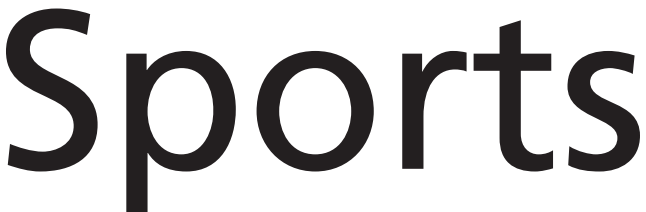 \\ Participation, Trainability and Readiness}


Part 1:

PARTICIPATION 


\title{
CHAPTER 3: PARTICIPATION IN ORGANIZED SPORT AMONG URBAN MEXICAN YOUTH
}

\author{
Shannon R Siegel \\ Maria E Peña Reyes \\ Eyra E Cárdenas Barahona [†] \\ Robert M Malina
}

\section{INTRODUCTION}

Although the structure of youth sport programs varies among countries (De Knop et al., 1996), it is reasonably well established that significant numbers of children and adolescents throughout the world are involved in organized sport. Organized youth sport implies the presence of a coach, and regular practices and competitions during the course of a season. Sport offerings vary with cultural context, and it is generally assumed that European football (soccer) is the most popular youth sport in the world. In addition to organized sports, youth throughout the world participate in informal sport activities on a regular basis.

Many children begin participating in sport during childhood, often by 6 or 7 years of age, and participation rates increase with age during childhood. Rates subsequently decline during the transition into adolescence, i.e., after about 12-13 years of age, and through adolescence. The decline in youth sports participation after 12-13 years parallels declining rates of participation in physical activities in general across adolescence (Malina, 1995).

Given the age-related pattern of participation in organized sport, questions related to the motives of children and adolescents to participate, to discontinue participation and to return to participation often surface in the sport-related literature. This study considers motivation for sport in urban Mexican youth 9-18 years of age.

\section{METHODS}

A survey of the growth status, physical activity and sport participation of approximately II00 urban Mexican school youth 9-18 years of age was conducted in 1998. A subsample of 59l youth completed questionnaires 
dealing with sport participation. This sample comprises the basis for this report.

The structure of the school system in Mexico includes the primaria (grades 1-6, approximately 6-12 years), secundaria (middle school with three grades, approximately $13-15$ years of age), and preparatoria (high school with three grades, approximately 15-18 years of age). Compulsory schooling requires that children attend until they are 16 years of age; hence. many do not complete high school. The sample was derived from the upper grades of the primaria (grades 4,5 and 6) and from secundaria and preparatoria in zones of the Federal District that could be classified as low, middle and upper socioeconomic status (SES).

The sample included 292 boys, among whom 168 (58\%) were involved in an organized sport at the time of the survey, and 299 girls, among whom 109 (36\%) were involved in an organized sport at the time of the survey. Sixteen boys and 22 girls were previously active in organized sport but were no longer active. As noted earlier, an organized sport implied the presence of a coach, and regular practices and competitions during the course of a season.

Four questionnaires, all in Spanish, were used. The first instrument was administered to the total sample of 59l students. It included basic demographic information, current sport participation status, level of physical activity, television and video game habits, perceived level of physical fitness, and perceived level of physical activity relative to peers. The three other instruments were Spanish translations of questionnaires used in a national survey of American youth 10-18 years of age in the mid-1980s (Ewing and Seefeldt, 1988). The questionnaires were field tested and modified as needed, albeit slightly, to fit the cultural context of Mexico.

A questionnaire related to reasons for participating in sport was administered to those who were currently (168 males, 109 females) or previously (16 males, 22 females) active in an organized sport (totals: 184 males, 131 females). It asked the youth 9-18 years of age to rate on a fivepoint scale 26 items related to reasons for participating in sport. Another questionnaire related to reasons for discontinuation of participation in sport was administered to high school youth 14 -18 years of age who were no longer active in organized sport (7I males, 88 females). It asked the youth to rate on a five-point scale 42 items related to why they discontinued participation in organized sports. A third questionnaire related to reasons for returning to sport participation was administered to high school youth 14-18 years of age who were no longer active in sport (66 males, 83 females). It asked the youth to rate on a five-point scale 22 items in response to the statement: "I would return to sport if...". 


\section{RESULTS}

\section{a) Sport Preferences}

The sports indicated by the youth are summarized in Table I. The preferred sport for boys was European football (soccer), followed by basketball, swimming, American football and baseball. The preferred sport for girls was basketball, followed by swimming, gymnastics, skating and volleyball.

Table I. Organized sports reported by urban Mexican youth 9-18 years of age who were active in sport at the time of the survey. Percentages do not add to $100 \%$ because many youth participated in more than one sport.

\begin{tabular}{lcc|lcc}
\hline Boys & $\mathrm{N}$ & $\%$ & Girls & $\mathrm{n}$ & $\%$ \\
\hline I. Football (soccer) & 128 & 76 & I. Basketball & 70 & 64 \\
2. Basketball & 97 & 58 & 2. Swimming & 61 & 56 \\
3. Swimming & 80 & 48 & 3. Gymnastics & 47 & 43 \\
4. Football (American) & 57 & 34 & 4. Skating' & 47 & 43 \\
5. Baseball & 49 & 29 & 5. Volleyball & 47 & 43 \\
6. Skating' & 47 & 28 & 6. Tennis & 28 & 26 \\
7. Tennis & 39 & 23 & 7. Football (soccer) & 27 & 25 \\
8. Volleyball & 37 & 22 & 8. Athletics & 20 & 18 \\
9. Bowling & 28 & 17 & 9. Bowling & 18 & 17 \\
10. Athletics & 26 & 15 & 10. Baseball (softball) & 17 & 16 \\
II. Gymnastics & 24 & 14 & II. Football (American) & 17 & 16 \\
12. Wrestling & 15 & 9 & 12. Wrestling & 9 & 8 \\
13. Others & 44 & 26 & I3. Others & 36 & 33 \\
\hline
\end{tabular}

IIn-line and roller skating. ${ }^{2}$ Other sports included martial arts, squash and racquetball among boys and dance and martial arts among girls.

Age variation was suggested in several sports. Among boys 9- 13 years, soccer was the preferred sport for $83 \%$ (66 of 80 ), whereas among boys $14-18$ years, soccer was the preferred sport for $70 \%$ (7I of 87 ). Soccer was followed in popularity by basketball, swimming and skating among the younger boys, while it was followed in popularity by swimming, basketball and American football among older boys. Among girls 9-13 years $(n=46)$, approximately equal numbers participated in skating (34,74\%), swimming (31, $67 \%)$ and basketball (30,65\%), followed by a slightly smaller number in volleyball (27, 59\%). Among girls $14-18$ years $(n=63)$, on the other hand, the majority participated in basketball (40,63\%), followed by swimming (30,48\%), skating (26, $41 \%)$ and gymnastics (24, 28\%).

Variation in sport by SES was also suggested. Soccer was the most common sport among low and middle SES boys, but ranked third among high SES boys, among whom swimming was the most popular sport. Basketball was second in popularity among boys in the three SES categories. 
Interestingly, baseball, which has a long tradition in Mexico (there is an active professional league), ranked fourth among low SES boys and sixth among middle and high SES boys. American football, on the other hand, ranked higher than baseball among middle and high SES boys.

In contrast to boys, there was very little SES variation among girls. Basketball was ranked first among girls in the three SES categories. Basketball was followed by skating, swimming and gymnastics among low and middle SES girls; volleyball replaced gymnastics among high SES girls.

\section{b) Sport Participants and Non-Participants}

Sport participants and non-participants were compared in several questions related to physical activity, physical fitness and physical inactivity (television, video games). Comparisons were made with ANCOVA with age as the covariate. Sport participants of both sexes were significantly younger $(p<0.05)$ and more physically active $(p<0.05)$ than non-participants. Sport participants also perceived themselves as having a better level of physical fitness $(p<0.05)$ and a higher level of physical activity compared to their peers $(p<0.05$ in females, $p=0.06$ in males). On the other hand, participants and nonparticipants in sport did not differ significantly in reported time watching television and playing video games.

\section{c) Motivation for Sport}

The ten highest ranked reasons for participating in sport are summarized in Table 2. The motives are remarkably similar between boys and girls. Fun is the primary motivation for participating in sport. Motives that follow fun focus on physical fitness, exercise, getting rid of excess energy and skill development. These highlight the role of sport in meeting the physical activity and healthand performance-related fitness needs of youth.

Table 2. Ten most important reasons for participating in organized sports among urban Mexican school children 9- 18 years of age.

\begin{tabular}{cl|ll}
\hline \multicolumn{1}{c|}{ Boys } & \multicolumn{1}{c}{ Girls } \\
\hline I. & To have fun & I. & To have fun \\
2. & To be physically fit & 2. & To be physically fit \\
3. & To get exercise & 3. & To get exercise \\
4. & To get rid of energy & To get rid of energy \\
5. & To improve my skills & $5 . \quad$ To improve my skills \\
6. & To do something at which I am good & $6 . \quad$ To do something at which I am good \\
7. & To learn new skills & 7. & For the excitement of competition \\
8. & For the excitement of competition & To learn new skills \\
9. & For the challenge of competition & To have something to do \\
10. & To get to a higher level of competition & I0. To be with my friends \\
\hline
\end{tabular}


Competition-related motives appear among the top ten motives for participating in sport in boys (items $8-10$ in Table 2) compared to girls (item 7). It is of interest that winning does not appear among the ten highest ranked motives for participating in sport. Winning ranked $13^{\text {th }}$ and $14^{\text {th }}$ among reasons for participating in sport in boys and girls, respectively.

An exploratory factor analysis was conducted to evaluate the clustering of motives for participation in sport. Four clusters of motives (factors) accounted for about $43 \%$ of the variance in the sample. Nine items loaded on a factor that was labeled as recognition or external awards and accounted for $17 \%$ of the variance. Four items loaded on a factor that could be labeled as physical fitness and accounted for 12\% of the variance. The three competition items formed a cluster labeled as a competition factor and accounted for $9 \%$ of the variance. Three items, including the fun item, clustered to form an outside activity factor and accounted for an additional 5\% of the variance. Overall, factor scores differed significantly between boys and girls $(p \leq 0.00 \mathrm{I})$, and subsequent univariate F-tests indicated significant sex differences in the three factors. Girls scored significantly higher on the factor related to recognition or external awards $(p \leq 0.001)$, while boys scored significantly higher on the factors related to competition $(p \leq 0.001)$ and outside activity $(p \leq 0.05)$.

\section{d) Motives for Discontinuing Sport}

Table 3. Ten most important reasons for discontinuing participation in sport among urban Mexican youth 14-18 years of age

\begin{tabular}{|c|c|c|}
\hline \multicolumn{2}{|r|}{ Boys } & Girls \\
\hline I. & $\begin{array}{l}\text { The games and practices were scheduled at } \\
\text { times when I could not attend }\end{array}$ & I. I needed more time to study \\
\hline 2. & I needed more time to study & The sport required too much time \\
\hline 3. & The sport required too much time & $\begin{array}{l}\text { 3. The games and practices were scheduled at } \\
\text { times when I could not attend }\end{array}$ \\
\hline 4. & Too much emphasis on winning & $\begin{array}{l}\text { 4. I could not afford to play and practice year } \\
\text { round }\end{array}$ \\
\hline 5. & I was not having fun & There was too much pressure \\
\hline 6. & There was too much pressure & My coach was a poor teacher \\
\hline 7. & My coach was a poor teacher & I did not have the opportunity to play much \\
\hline 8. & $\begin{array}{l}\text { I could not afford to play and practice year } \\
\text { round }\end{array}$ & $\begin{array}{l}\text { 8. I wanted to participate in other non-sport } \\
\text { activities }\end{array}$ \\
\hline 9. & I was no longer interested in the sport & 9. I was no longer interested in the sport \\
\hline 10. & $\begin{array}{l}\text { I wanted to participate in other non-sport } \\
\text { activities }\end{array}$ & 10. The coach played only his/her favorite players \\
\hline
\end{tabular}

As noted earlier, this questionnaire was administered only to high school students 14-18 years of age. The ten highest ranked reasons for discontinuing 
participation in sport are summarized in Table 3. Although the order of the top ten motives differs slightly between boys and girls, the choices themselves are quite similar. The first three reasons for discontinuing participation in sport in both boys and girls relate to time - time for study, time demands of the sport, and time conflicts. Both boys and girls note the potentially negative influence of pressure related to sport and the ability or role the coach as a teacher. Girls also indicate two other coach-related potentially negative influences, favoritism and lack of playing time.

Both boys and girls also note the role of changing interests and desire to participate in non-sport activities as factors influencing the decision to discontinue participation in sport. This highlights normal changes in adolescent behaviors and interests which are unrelated to sport.

Table 4. Ten most highly ranked responses to the statement: "I would return to sport if...." in urban Mexican youth 14- 18 years of age.

\begin{tabular}{|c|c|c|c|}
\hline \multicolumn{2}{|r|}{ Boys } & \multicolumn{2}{|r|}{ Girls } \\
\hline l. & $\begin{array}{l}\text { The practices or games did not conflict } \\
\text { with my studies }\end{array}$ & I. & $\begin{array}{l}\text { The practices or games did not conflict with } \\
\text { my studies }\end{array}$ \\
\hline 2. & $\begin{array}{l}\text { The games and practices were scheduled } \\
\text { at other times }\end{array}$ & 2. & $\begin{array}{l}\text { The games and practices were scheduled at } \\
\text { other times }\end{array}$ \\
\hline 3. & I could play more & 3. & $\begin{array}{l}\text { The practices or games did not interfere with } \\
\text { my social life }\end{array}$ \\
\hline 4. & $\begin{array}{l}\text { The games or practices did not interfere } \\
\text { with my social life }\end{array}$ & 4. & The sport did not demand so much time \\
\hline 5. & The sport did not demand so much time & 5. & I could play more \\
\hline 6. & The practices were more fun & 6. & There were more or closer practice facilities \\
\hline 7. & $\begin{array}{l}\text { There were more or closer practice } \\
\text { facilities }\end{array}$ & 7. & The coach was a better instructor \\
\hline 8. & $\begin{array}{l}\text { There were more leagues so the other } \\
\text { players were closer to my ability level }\end{array}$ & 8. & The coaches understood the players better \\
\hline 9. & The coaches understood the players better & 9. & The practices were more fun \\
\hline 10. & The coach was a better instructor & 10. & $\begin{array}{l}\text { There were more leagues so the other } \\
\text { players were closer to my ability level }\end{array}$ \\
\hline
\end{tabular}

\section{e) Returning to Sport}

Changes in sport that would be conducive to attracting youth to return to participation in organized sport are summarized in Table 4. As in motives for participation and discontinuing participation, responses to the statement, "I would return to sport if...," are remarkably similar in boys and girls. Four of the five highest ranked reasons relate to time and social life in both sexes time for study, time conflicts, time demands, and interference with social life. The fifth item (ranked $3^{\text {rd }}$ in boys and $5^{\text {th }}$ in girls) relates to playing time, a factor controlled by coaches. Three of the items ranked between $6^{\text {th }}$ and $10^{\text {th }}$ relate primarily to coaches - teaching ability, practices and understanding of 
players. The final two items relate to sport or league administration proximity of practice facilities and ability level of players.

\section{DISCUSSION}

The results of the survey of Mexican youth, though limited in numbers to school youth in the Federal District (Mexico City), need to be viewed in the context of sport preferences and sport availability in different countries. Mexico, for example, does not have highly developed high school sport programs as in the United States. Moreover, organized sport programs are more readily available in the larger urban centers in contrast to rural areas of the country. In this survey of urban Mexican youth, the five most popular sports for boys, in order of preference, were soccer, basketball, swimming, American football and baseball. The five most popular sport activities for urban Mexican girls, in order of preference, were basketball, swimming, gymnastics, volleyball and skating. Skating (in-line or roller skating) is most often a recreational sport, although competitive skating programs are increasing in number. There was, however, variation with age in the Mexican sample. Soccer was the highest ranking sport for boys across all ages. Among boys 9-13 years of age, soccer was followed by basketball, swimming, skating and baseball; among boys 14-18 years, soccer was followed by swimming basketball, American football and baseball. Skating was the most popular sport activity for Mexican girls 9-13 years, whereas basketball was the popular sport in girls 14- 18 years.

The most popular organized sports for American youth 6-17 years of age, based on numbers of participants in 2000, were as follows: boys baseball, basketball, soccer, American football, athletics; girls - soccer, basketball, softball, volleyball, cheerleading (Sporting Goods Manufacturers Association, 200I). The statistics include community- and school-based sports with regularly scheduled games. If the estimates are combined for boys and girls, soccer is now the second most popular sport among American youth. The numbers are estimates and some youth participate in more than one sport. For example, among organized sport participants 6-17 years of age in the United States, 44\% played one sport, 30\% played two sports, $17 \%$ played three sports, and $9 \%$ played four or more sports (Sporting Goods Manufacturers Association, 200I).

More specific estimates for high school sports in the 1999-2000 school year indicated about 3.9 million (26\%) boys and 2.7 million (I8\%) girls in grades 9-12 (approximately $14-18$ years of age) who participated on interschool sport teams. The five most popular high school sports based on numbers of participants in 1999-2000 are as follows: boys - American football, 
basketball, athletics, baseball, soccer; girls - basketball, athletics, volleyball, softball, soccer. The number of male and female participants in high school soccer in the United States increased dramatically from 1989-1990 to 1999 2000, by approximately 50\% in boys and $142 \%$ in girls (Malina, 2002).

Table 5. Ten most important reasons for participating in organized sports among Mexican boys 9- 18 years of age and American boys $10-18$ years of age.

\begin{tabular}{|c|c|c|}
\hline & $\begin{array}{l}\text { Mexican Boys } \\
\text { (present study) }\end{array}$ & $\begin{array}{c}\text { American Boys } \\
\text { (Adapted from Ewing and Seefeldt, 1988). }\end{array}$ \\
\hline I. & To have fun & I. To have fun \\
\hline 2. & To be physically fit & To do something I am good at \\
\hline 3. & To get exercise & To improve my skills \\
\hline 4. & To get rid of energy & For the excitement of competition \\
\hline 5. & To improve my skills & To stay in shape \\
\hline 6. & To do something at which I am good & For the challenge of competition \\
\hline 7. & To learn new skills & To get exercise \\
\hline 8. & For the excitement of competition & To learn new skills \\
\hline 9. & For the challenge of competition & To play as a part of a team \\
\hline 10. & To get to a higher level of competition & To go to a higher level of competition \\
\hline
\end{tabular}

Table 6. Ten most important reasons for participating in sport among Mexican girls 9-18 years of age and American girls $10-18$ years of age

\begin{tabular}{|c|c|c|}
\hline & $\begin{array}{l}\text { Mexican Girls } \\
\text { (present study) }\end{array}$ & $\begin{array}{c}\text { American Girls } \\
\text { (Adapted from Ewing and Seefeldt, 1988). }\end{array}$ \\
\hline 1. & To have fun & To have fun \\
\hline 2. & To be physically fit & To stay in shape \\
\hline 3. & To get exercise & To get exercise \\
\hline 4. & To get rid of energy & To improve my skills \\
\hline 5. & To improve my skills & To do something I am good at \\
\hline 6. & To do something at which I am good & To learn new skills \\
\hline 7. & For the excitement of competition & For the excitement of competition \\
\hline 8. & To learn new skills & To play as a part of a team \\
\hline 9. & To have something to do & To make new friends \\
\hline 10. & To be with my friends & For the challenge of competition \\
\hline
\end{tabular}

The structure of competitive sport programs in Mexico and the United States is different. Many sport programs are centered in clubs in contrast to community and municipal entities, although the number of interschool sport offerings in Mexico, especially in larger urban centers, is increasing. In addition to local cultural influences, the structure of the programs, of course, may influence the sports available to youth

The reasons why children and adolescents of both sexes participate in sport included the following: to have fun, to improve skills and to learn new skills, to be with friends or to make new friends, for thrills and excitement, to get physical activity (exercise), and to become physically fit, among others. 
With few exceptions, the reasons stated by Mexican youth 9-1 8 years of age for participation in sport are quite similar to those stated by American youth 10-18 years of age (Tables 5 and 6). The data for American youth were from a national sample surveyed in the late 1980s (Ewing and Seefeldt, 1989), whereas those for Mexican youth were collected in 1998. Fun (enjoyment), skill learning and socialization are central to the why children participate in sport.

Table 7. Ten most important reasons for discontinuing participation in sport among Mexican boys 14- 18 years of age and American boys 10 - 18 years of age.

\begin{tabular}{|c|c|c|}
\hline & $\begin{array}{l}\text { Mexican Boys } \\
\text { (present study) }\end{array}$ & $\begin{array}{c}\text { American Boys } \\
\text { (Adapted from Ewing and Seefeldt, 1988) }\end{array}$ \\
\hline I. & $\begin{array}{l}\text { The games and practices were scheduled } \\
\text { at times when I could not attend }\end{array}$ & I was no longer interested in the sport \\
\hline 2. & I needed more time to study & I was not having fun \\
\hline 3. & The sport required too much time & The sport required too much time \\
\hline 4. & Too much emphasis on winning & The coach played favorites \\
\hline 5. & I was not having fun & The coach was a poor teacher \\
\hline 6. & There was too much pressure & I was tired of playing \\
\hline 7. & My coach was a poor teacher & Too much emphasis on winning \\
\hline 8. & $\begin{array}{l}\text { I could not afford to play and practice year } \\
\text { round }\end{array}$ & $\begin{array}{l}\text { I wanted to participate in other non-sport } \\
\text { activities }\end{array}$ \\
\hline 9. & I was no longer interested in the sport & I needed more time to study \\
\hline 10. & $\begin{array}{l}\text { I wanted to participate in other non-sport } \\
\text { activities }\end{array}$ & There was too much pressure \\
\hline
\end{tabular}

Reasons for discontinuing participation in sport stated by Mexican and American youth are summarized in Tables 7 and 8 . Changing interests, lack of fun or enjoyment in sport, and several coach-related behaviors are associated with discontinuation of sport " in American youth of both sexes. Changing interests and attempts at new and different activities are related to normal behavioral development as youth enter and progress through adolescence. In contrast to American youth, time commitment to sport is a major concern associated with discontinuation of sport among urban Mexican youth. Mexican youth rank the time commitment for study more highly, i.e., sport participation takes up too much time and it may reduce time available for study. However, females rank the need for more time to study more highly than males. Coaching concerns, pressure to win and lack of interest also surface as reasons for discontinuing sport among Mexican youth.

Presently available data on motivation for participation in sport and for discontinuation of sport are general, do not consider specific sports, and do not account for changes in descriptive terms with age. Cultural variation is an additional factor. For example, the meaning of "what is fun in sports" probably differs with age and perhaps among specific sports and type of sport program (community-based, recreational, club, interscholastic). Systematic 
data are not extensive for specific factors indicated as related to discontinuation in a sport. Important considerations include, among others, type of program, structure of the sport organization, level of competition, intensity of training and competition, individual differences in growth, maturation and development, status of the individual on a team or club, and cultural variation in adolescent time and school demands. An important role for coach behaviors and quality of coaching in motivation to continue or discontinue in a sport is indicated.

Table 8. Ten most important reasons for discontinuing participation in sport among Mexican girls $14-18$ years of age and American girls $10-18$ years of age

\begin{tabular}{|c|c|c|c|}
\hline \multicolumn{2}{|r|}{$\begin{array}{c}\text { Mexican Girls } \\
\text { (present study) }\end{array}$} & \multicolumn{2}{|r|}{$\begin{array}{c}\text { American Girls } \\
\text { (Adapted from Ewing and Seefeldt, 1988) }\end{array}$} \\
\hline l. & I needed more time to study & l. & I was no longer interested in the sport \\
\hline 2. & The sport required too much time & 2. & I was not having fun \\
\hline 3. & $\begin{array}{l}\text { The games and practices were scheduled at } \\
\text { times when I could not attend }\end{array}$ & 3. & I needed more time to study \\
\hline 4. & $\begin{array}{l}\text { I could not afford to play and practice year } \\
\text { round }\end{array}$ & 4. & There was too much pressure \\
\hline 5. & There was too much pressure & 5. & The coach was a poor teacher \\
\hline 6. & My coach was a poor teacher & 6. & $\begin{array}{l}\text { I wanted to participate in other non-sport } \\
\text { activities }\end{array}$ \\
\hline 7. & $\begin{array}{l}\text { I did not have the opportunity to play } \\
\text { much }\end{array}$ & 7. & The sport required too much time \\
\hline 8. & $\begin{array}{l}\text { I wanted to participate in other non-sport } \\
\text { activities }\end{array}$ & 8. & The coach played favorites \\
\hline 9. & I was no longer interested in the sport & 9. & I was tired of playing \\
\hline 10. & $\begin{array}{l}\text { The coach played only his/her favorite } \\
\text { players }\end{array}$ & 10. & $\begin{array}{l}\text { Games and practices were scheduled at } \\
\text { times when I could not attend }\end{array}$ \\
\hline
\end{tabular}

In the total sample of Mexican youth $(n=591)$, sport participants reported higher levels of overall physical activity compared to non-sport participants. This is consistent with observations of American youth active and non-active in organized sports. Youth active in sport expended more energy in physical activity than those who were not active in sport (Katzmarzyk and Malina, 1998). The American study differed from the Mexican data in that American youth active in sport also spent less time viewing television, i.e., being inactive, whereas sport participants and non-participants in the Mexican survey did not differ in reported time viewing television and playing video games.

There is also the possibility that those with a history of participation in youth sports may more physically active as adults, but data to this effect are limited (Engstrom, 1986, 1991; Kuh and Cooper, 1992; see also Malina, 2001). Instruction and practice associated with sports programs contribute to development and refinement of a variety of sport specific motor skills, which provide the foundation for other skills and for an active life style. However, children should be given a voice or a choice in their sport participation. Being 
forced to exercise during childhood may have potentially negative consequences for later activity (Taylor et al., 1999).

\section{REFERENCES}

DeKnop P, Engstrom LM, Skirstad B, Weiss MR (1996) Worldwide Trends in Youth Sport. Champaign, IL: Human Kinetics.

Engstrom LM (1986) The process of socialization into keep fit activities. Journal of Sports Science. 8: 89-97.

Engstrom LM (199|) Exercise adherence in sport for all from youth to adulthood. In P Oja, R Telama (eds): Sport for All. Amsterdam: Elsevier Press. pp 473-483.

Ewing ME, Seefeldt V (1988) Participation and attrition patterns in American agencysponsored and interscholastic sports: An executive summary. East Lansing: Michigan State University. Institute for the Study of Youth Sports.

Katzmarzyk PT, Malina RM (1998) Contributions of organized sports participation to estimated daily energy expenditure in youth. Pediatric Exercise Science 10:378-386.

Kuh DJL, Cooper C (1992) Physical activity at 36 years: Patterns and childhood predictors in a longitudinal study. Journal of Epidemiology and Community Health 46:114-119.

Malina RM (1995) Physical activity and fitness of children and youth: Questions and implications. Medicine Exercise Nutrition and Health. 4:I23-I 35.

Malina RM (200I) Tracking of physical activity across the lifespan. President's Council on Physical Fitness and Sports Research Digest. Series 3. No. 14 (September).

Malina RM (2002) Sports. school. In JW Guthrie (ed): The Encyclopedia of Education. $2^{\text {nd }}$ edition. New York: Macmillan Reference USA, pp 2305-23I 2.

Sporting Goods Manufacturers Association (200I) U.S. Trends in Team Sports: 2001 Edition. North Palm Beach, FL: Sporting Goods Manufacturers Association.

Taylor WC, Blair SN, Cummings SS, Wun CC, Malina RM (1999) Childhood and adolescent physical activity patterns and adult physical activity. Medicine and Science in Sports and Exercise 31:1 18-123.

ACKNOWLEDGMENT: This research was supported in part by a grant to Robert Malina from the International Education Program at Michigan State University. The support of Dr. Jack Schwille is gratefully acknowledged and appreciated. 
Série

Investigação

Imprensa da Universidade de Coimbra

Coimbra University Press

2009

U

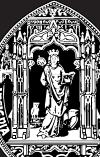

C 